DOI: $10.21802 /$ artm.2020.3.15.43.

УДК 616-071+616.12-009.7+616.127-005.8

\title{
ВИКОРИСТАННЯ ШКАЛИ НЕАRТ ДЛЯ ДИФЕРЕНЦАЦЇ̈ ЗАГРУДИННОГО БОЛЮ У ХВОРИХ ІЗ ПІДОЗРОЮ НА ГОСТРИЙ ІНФАРКТ МІОКАРДА
}

\section{O.I. Готюр}

Івано-Франківський національний медичний університет, кафедра внутрішньої медицинии №2 та медсестринства, м. Івано-Франківськ, Україна, ORCID ID: 0000-0001-9687-0112,e-mail: Oksanahotiur@gmail.com

Резюме. Мета дослідження. Провести диференціацію хворих із загрудинним больовим синдромом, що потенційно могли бути зараженими COVID-19 з низьким, середнім та високим ризиком виникнення «великої побічної серцевої події».

Матеріали і методи. Нами було проведено диференціацію 50 випадків звернень у відділення екстреної допомоги, що мали симптом вираженого загрудинного больового синдрому неясного генезу. Серед пацієнтів було 5 потенційно хворих на COVID-19. Переважали чоловіки, віком від 20 до 70 років (середній вік 49,02 $\pm 1,73$ роки). Усім паціснтам проводили підрахунок балів за шкалою HEART (анамнез, вік, фактори ризику (куріння, ожиріння, сімейний анамнез, гіперхолестеринемія, АГ, ЦД, захворювання периферичних артерій), дані ЕКГ, рівень тропоніну I).

Результати дослідження. Під час підрахунку балів за шкалою HEART нами було виявлено $20 \%$ осіб iз низьким ризиком розвитку MACE $(2,4 \pm 0,12$ бали), $44 \%$ - проміжний ризик $(5,18 \pm 0,16$ бали), із високим ризиком $-36 \%(7,83 \pm 0,26$ бали).

Серед 5-ти потенційно хворих на COVID-19, що мали скарги на загрудинний біль та елевацію сегмента ST на ЕКГ, після проведення PLR-тестів мали низькі рівні Тропоніну I та підтвердження вірусу COVID-19 iз подальшою госпіталізацією в інфекційну лікарню.

Пацієнти із низьким ризиком МАСЕ не потребували госпіталізації і спеціальних обстежень. Загрудинний біль у них супроводжував фізичне та психоемоційне напруження, захворювання опорно-рухового апарату, вегето-судинну дисфункцію.

Висновки. Прогнозування результатів у хворих із загруднинним болем у хворих із гострим інфарктом міокарда, які звертаються в екстрену медичну допомогу, визначаються за допомогою шкали HEART. Значна кількість хворих, що мають проміжний або високий ризик розвитку МАСЕ, повинні негайно госпіталізовуватися до стаціонару.

Ключові слова: шкала HEART, серцево-судинний ризик.

Вступ. За період карантину стан здоров'я населення України значно погіршився. Постійна стресова напруга, спричинена небезпекою можливого зараження вірусом COVID-19, призвела до загострення всіх хронічних хвороб. Страх перед високим ризиком зараження вірусною інфекцією в період карантину спонукала пацієнтів до нехтування своїм фізичним станом і не звертатися за допомогою до вузьких спеціалістів, що призвело до серйозних наслідків (прогресування та ускладнень) хронічних захворювань.

Як показали спостереження кардіологів та сімейних лікарів, надмірне споживанням великої кількості висококалорійних продуктів та карантинні обмеження прогулянок серед кардіологічних хворих сприяли накопиченню жиру та збільшення індексу маси тіла у них.

У розвитку та прогресуванні СC3 значна роль належить факторам ризику. Численні індивідуальні характеристики сприяють розвитку СС3, включаючи стать, вік, концентрацію ліпідів у крові, підвищений артеріальний тиск, порушення толерантності до глюкози, ожиріння, куріння тощо [3].
Провідні спеціалісти нашої планети для оцінки ризику СС3 у рутинній клінічній практиці застосовують численні статистичні підходи Фремінгемська шкала, шкали SCORE, HEART, PROCAM та інші, які мають один перед одни певні переваги та недоліки. Використання вказаних методик передбачене для розрахунку кардіоваскулярного ризику для загальної популяції.

Основними перевагами є: нестандартний та уніфікований підхід для прийняття рішення; відсутність суттєвої залежності від досвіду та спеціалізації лікаря; можливість кількісно прогнозувати стабілізацію стану пацієнта та мінімізувати людський фактор похибок, адже використовується автоматична реєстрація та розрахунок показників.

Недоліками цих шкал виступає перш за все груповий прогноз та облік невеликого числа предикторів, а також: не можливість визначення часового проміжку для прогнозу виникнення ускладнень; прямий вплив виду популяції на результат; відсутність стандартів та складність вибору серед різноманітних видів шкал; ці шкали не дають можливості досліджувати всі хвороби. 
Швидка й точна діагностика серцевосудинних захворювань (СС3), вибір лікувальної програми 3 обгрунтованим співвідношенням «користь/ризик» для практикуючого кардіолога є головною метою у наданні кардіологічної допомоги. Сучасні технологічні та лабораторні можливості пропонують новітні вдосконалені підходи для діагностики та лікування пацієнтів із СС3 $[6,7]$.

У час епідемії важливою $є$ швидка диференціація пацієнтів із симптомом загрудинного болю, за яким може маскуватися як закид щлункового вмісту у стравохід, зміна рh-шлункового вмісту, міжреберна невралгія, онко-патологія органів грудної клітки, COVID, так і інша патологія. Тому зараз $є$ актуальним використання різноманітних шкал для визначення оцінки виникнення будь якої патології, а особливо гострих станів у кардіології як діагностики сьогодні чи прогнозування в майбутньому ускладнень [1].

HEART Score - використовується для пацієнтів у приймальному відділенні чи у машині швидкої допомоги у яких наявний гострий загруднинний боль [2].
Вилику допомогу у розподілі пацієнтів 3 різними рівнями ризику виникнення патології та ускладнення, на базі багатьох доказових досліджень була представлена саме шкала HEART як практичний, але доступний інструмент для будь-якого лікаря невідкладної допомоги. Вона базується на обчисленні ризику «великої побічної серцевої події» (Major Adverse Cardiac Event (MACE)) протягом 6 тижнів, таких як загальна смертність, IM або коронарна реваскуляризація (табл. 1.).

Пацієнти, які набрали 0-3 бали, мають 0,9$1,7 \%$ ризику несприятливих серцевих подій; оцінка 4-6 балів: 12-16,6 \% ризику несприятливих серцевих подій, оцінка $\geq 7:$ 50-65 \% ризику несприятливих серцевих подій (кандидатами на ранні інвазивні заходи). Відповідно до шкали HEART відразу зрозуміло, який пацієнт має право на виписку без додаткових аналізів або екстрених інвазивних процедур.

Шкала HEART не використовується, якщо на ЕКГ реєструється нова елевація сегмента $\mathrm{ST} \geq 1$ мм або інші нові ЕКГ зміни, які вимагають негайного втручання; гіпотензія; тривалість життя менше 1 року або позасерцева / хірургічна /психіатрична хвороба або в клінічно нестабільних пацієнтів [2, 5, 6].

Таблиця 1

HEART Score для паціснтів із загруднинним болем

\begin{tabular}{|c|c|c|c|}
\hline & & Показник & Бал \\
\hline \multirow{3}{*}{$\mathbf{H}$} & \multirow{3}{*}{ History/Анемнез * } & Викликають слабку підозру & $\mathbf{0}$ \\
\hline & & Середній ступінь настороженості & 1 \\
\hline & & Високий ступінь настороженості & 2 \\
\hline \multirow{3}{*}{$\mathbf{E}$} & \multirow{3}{*}{ ECG / Електрокардіограма } & Норма & $\mathbf{0}$ \\
\hline & & 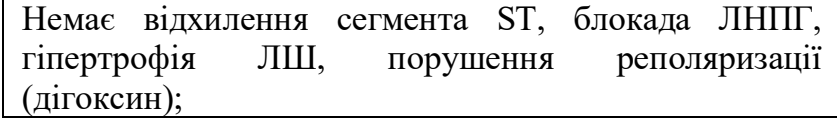 & 1 \\
\hline & & Виражене відхилення сегмента ST & 2 \\
\hline \multirow{3}{*}{ A } & \multirow{3}{*}{ Age/Вiк } & $<45$ & $\mathbf{0}$ \\
\hline & & $45-64$ & 1 \\
\hline & & $\geq 65$ & 2 \\
\hline \multirow{3}{*}{$\mathbf{R}$} & \multirow{3}{*}{ Risk factors/Фактори ризику** } & Відсутні & $\mathbf{0}$ \\
\hline & & 1 - 2 фактори ризику & 1 \\
\hline & & $\geq 3$ факторів ризику або атеросклероз в анамнезі & 2 \\
\hline \multirow{3}{*}{$\mathbf{T}$} & \multirow{3}{*}{$\begin{array}{l}\text { Initial troponin/ Рівень тро- } \\
\text { поніну }\end{array}$} & $\leq$ норми & $\mathbf{0}$ \\
\hline & & 1-3 х норми & 1 \\
\hline & & $>3$ х норми & 2 \\
\hline
\end{tabular}

Примітки. *Біль у грудях, що здавлює, іррадіація в щелепу / ліве плече / руку, тривалість 5-15 хв, причина: фізичне навантаження, холод, стрес, нудота / блювання, позитивна реакція на нітрати упродовж декількох хвилин, підтвердження симптомів пацієнтом. Низький ризик: добре локалізований біль, не пов'язаний з фізичним навантаженням, відсутність підвищеного потовиділення, немає блювоти / нудоти, посилюється при пальпації.

** Фактори ризику: АГ, гіперхолестеринемія, ЦД, ожиріння (IMT >30 кг/м2), куріння (зараз або $\leq 3$ міс. тому), сімейний анамнез (батько або рідний брат/сестра молодше 65 років з СС3), що передують: IM, ЧКВ/АКШ, ТІА/ГРМК, захворювання периферичних артерій).

Обгрунтування дослідження. Серйозну проблему сьогодення становить інфекційна нестабільність в Україні через COVID-19, але серцево-судинні захворювання залишаються головною причиною смертності громадян країни. Судячи із статистичних відомостей, приблизно 40\% звернень до кардіолога у час пандемії - це хворі 3 порушеннями ритму та провідності (фібриляцією/тріпотінням передсердь) 3 різними ускладненнями: гострим коронарним синдромом (ГКС), інфарктом міокарда (IM), інсультом та іншими.

У цей період вірусного навантаження на країну спостерігається збільшення виникнення та прогресування серцевої недостатності втричі та збільшення ризику інфаркту міокарда, зростання 
ризику загальної смертності - вдвічі від серцево судинної патології. Саме тому сьогодні є надзвичайно важливим надання своєчасної долікарської та лікарської допомоги із правильним скеруванням пацієнтів із серцевою патологію у відповідні відділення для надання кваліфікаційної допомоги; у цьому може значно полегшити роботу для лікарів шкала HEART.

Мета дослідження. Провести диференціацію хворих із загрудинним больовим синдромом, що потенційно могли бути зараженим COVID-19 3 низьким, середнім та високим ризиком виникнення «великої побічної серцевої події» (Major Adverse Cardiac Event (MACE)) протягом 6 тижнів, таких як загальна смертність, IM, потреба в коронарній реваскуляризації чи аортокоронарному шунтуванні та смерть.

Матеріали та методи. Нами було проведено диференціацію 50 випадків звернень у відділення екстреної допомоги, що мали симптом вираженого загрудинного больового синдрому неясного генезу. Серед пацієнтів переважали чоловіки, віком від 20 до 70 років (середній вік 49,02 $\pm 1,73$ роки). Усім пацієнтам проводили підрахунок балів за шкалою HEART (анамнез, вік, фактори ризику (куріння, ожиріння, сімейний анамнез, гіперхолестеринемія, АГ, ЦД, захворювання периферичних артерій), дані ЕКГ, рівень тропоніну I), а також запитували, чи вони не хворіють у даний момент вірусною інфекцією та про можливий контакт із потенційними хворими на COVID-19.

Результати дослідження. Під час обстеження пацієнтів ми виявили різні фактори ризику, а саме: зареєстрували 32\% хворих, які мали стаж куріння більше 5-ти років, обтяжений сімейний анамнез виявили в $30 \%$ обстежених. Найбільш частим фактором ризику серед досліджених пацієнтів склала саме артеріальна гіпертензія - 54\% хворих мали коливання артеріального тиску. ЦД II типу був відмічений у $34 \%$, гіперхолистеринемія - 36\%, ожиріння - 20\%, захворювання переферійних судин - $18 \%$ пацієнтів.

Серед обстежених хворих БЛНПГ, БПНПГ, ГЛШ на ЕКГ спостерігалася у $42 \%$ хворих; елевація сегменту ST (2-3 мм), депресія сегменту ST, порушення процесів реполяризації - 58\% хворих. Підвищені рівні тропоніну I (1-3 рази вище норми) у 48\% хворих, і $>3$ х норм $-8 \%$ хворих.

Під час підрахунку балів за шкалою HEART нами було виявлено 20\% осіб із низьким ризиком розвитку MACE $(2,4 \pm 0,12$ бали), 44\% - проміжний ризик $(5,18 \pm 0,16$ бали), із високим ризиком - 36\% $(7,83 \pm 0,26$ бали).

5 пацієнтів, окрім загрунинного болю, відмічали підвищення температури тіла до $37,6{ }^{\circ} \mathrm{C}$ протягом 3-х днів, загальну слабість, відчуття нестачі повітря. За даними ЕКГ порушення процесів репорляризації, обтяжений сімейний анамнез. За даними рентгенографій органів грудної клітки - норма. Кількість балів за шкалою HEART у них 1,2 $\pm 0,2$ бали. Швидкий тест на COVID-19 дав позитивний результат. Троє хворих були скеровані на амбулаторне лікування, двоє - на стаціонарне лікування.
Пацієнти із низьким ризиком МАСЕ не потребували госпіталізації і спеціальних обстежень. Загрудинний біль у них супроводжував фізичне та психоемоційне напруження, захворювання опорнорухового апарату, вегето-судинну дисфункцію.

Обговорення результатів. Дана шкала є актуальною, простою у використанні для ідентифікації хворих із загрудинним болем. III можна застосовувати не тільки для стаціонарних пацієнтів, але й при поліклінічному прийомі та в амбулаторіях сімейної медицини.

Результати нашої роботи підтверджуються й іншими дослідженням в інших клініках світу та Свропи [3, 6].

Висновки. Прогнозування результатів у хворих із загруднинним болем та хворих із гострим інфарктом міокарда, які звертаються в екстрену медичну допомогу, визначаються за допомогою шкали HEART. Значна кількість хворих, що мають проміжний або високий ризик розвитку MACE, повинні негайно госпіталізовуватися до стаціонару.

\section{References:}

1. Belialov F. Prognosis and scores in cardiology. M: MEDpress-inform, 2018; P.300. (in Russ).

2. Vakaliuk IP, Serediuk NM, Denina RV, Baryla HH, Churpii IK, Yaniv OV. Zastosuvannia prohnostychnykh shkal u suchasnii kardiolohichnii praktytsi (chastyna 1). Art of Medicine. 1(13) 2020. P.180-193.

3. Vizir VA, Sadomov AS, Nasonenko OV. Otsinka sertsevo-sudynnoho ryzyku $\mathrm{V}$ cholovikiv iz hipertonichnoiu khvoroboiu na tli androhennoho defitsytu. Zdobutky klinichnoi i eksperymentalnoi medytsyny. 2018; 1:61-67.

4. Naqvi SHR, Abbas T, Tun HN, Naqvi AA, Zaffar Z, et al. Diagnostic accuracy of TIMI versus GRACE score for prediction of death in patients presenting with Acute Non-ST Elevation Myocardial Infarction (NSTEMI). J Cardiol Cardiovasc Med. 2019; 4:001005. https://doi.org/10.29328/journal.jccm.1001032.

5. Shekera OH, Kukharchuk KhM. Rannia otsinka rozvytku kardiovaskuliarnoi patolohii $\mathrm{u}$ bezsymptomnykh patsiientiv iz subklinichnym hipotyreozom. Semeinaia medytsyna. 2018; 2(76):4144.

6. Van Den Berg P, Body R. The HEART score for early rule out of acute coronary syndromes in the emergency department: a systematic review and metaanalysis. Eur Heart J Acute Cardiovasc Care, 2018; 7:111-119.

7. Yashchenko OB, Khimion LV, Danyliuk SV, Sytiuk TO. Ctabilna ishemichna khvoroba sertsia. Semeinaia medytsyna. 2018; 4(78):5-15. 
УДК 616-071+616.12-009.7+616.127-005.8

ИСПОЛЬЗОВАНИЕ ШКАЛЫ НЕАRТ ДЛЯ ДИФФЕРЕНЦИАЦИИ ЗАГРУДИННОЙ БОЛИ У БОЛЬНЫХ С ПОДОЗРЕНИЕМ НА ОСТРЫЙ ИНФАРКТ МИОКАРДА

О.И. Готюр

Ивано-Франковский национальный медицинский университет, кафедра внутренней медицинь №2 и медсестринства, г. Ивано-Франковск, Украина, ORCID ID: 0000-0001-9687-0112,

e-mail: Oksanahotiur@gmail.com

Резюме. Цель исследования. Провести дифференциацию больных с загрудынным болевым синдромом, что потенциально могли бы быть зараженными COVID-19 с низким, средним и высоким риском возникновения «большого побочного сердечного события».

Материалы и методы. Нами было проведено дифференциацию 50 случаев обращений пациентов в отделение экстренной помощи, что имели симптом боль за грудиной. Среди пациентов было 5 потенциально больных COVID-19. Преобладали мужчины в возрасте от 20 до 70 лет (средний возраст 49,02 $\pm 1,73$ года). Всем пациентам проводили подсчет баллов по шкале HEART (анамнез, возраст, факторы риска (курение, ожирение, семейный анамнез, гиперхолестеринемия, АГ, СД, заболевания периферических артерий), данные ЭКГ, уровень тропонина I).

Результаты исследования. При подсчете баллов по шкале HEART нами было выявлено 20\% лиц с низким риском развития $\mathrm{MACE}(2,4 \pm 0,12$ балла), 44\% - промежуточный риск $(5,18 \pm 0,16$ балла), с высоким риском - 36\% (7,83 $\pm 0,26$ балла).

Среди 5-ти потенциально больных COVID-19 имели жалобы на боль за грудиной и элевацию сегмента ST на ЭКГ, после проведения PLR-тестов имели низкие уровни тропонина I и подтверждение вируca COVID-19 с последующей госпитализацией в инфекционную больницу.

Пациенты с низким риском MACE не нуждались в госпитализации и специальных обследованиях. Боль за грудиной в них сопровождал физическое и психоэмоциональное напряжение, заболевания опорно-двигательного аппарата, вегето-сосудистой дисфункции.

Выводы. Прогнозирование результатов у больных с загрудинной болью у больных с острым инфарктом миокарда, обращающихся в экстренную медицинскую помощь, определяются с помощью шкалы HEART. Значительное количество больных, имеющих промежуточный или высокий риск развития МАСЕ, должны немедленно госпитализироваться в стационар.

Ключевые слова: шкала HEART, сердечнососудистый риск.

\section{UDC 616-071+616.12-009.7+616.127-005.8 \\ THE USE OF THE HEART SCORE FOR DIFFERENTIATION OF CHEST PAIN IN PATIENTS WITH ACUTE MYOCARDIAL INFARCTION}

\section{O.I. Hotiur}

Ivano-Frankivsk National Medical University, Department of Internal Medicine No2 and Nursing, Ivano-Frankivsk, Ukraine, ORCID ID: 0000-0001-9687-0112, e-mail: Oksanahotiur@gmail.com

Abstract. During the quarantine, the public health of Ukraine decreased significantly. Constant stress caused by the possibility of COVID-19 infection risk has caused the flare-up of chronic conditions.

At the moment of the epidemics, it is important to differentiate patients with chest pain quickly, while it may hide COVID-19 as well as other pathology. So, it is relevant to use different scales to evaluate risks for diseases at the moment (diagnostics) or in the future (prognosis).

Exactly to divide the patients into groups with low, intermediate, and high risk, many evidence-based studies presented the HEART score, as a practical, as well as available tool for any intensive care physician. It is based on the calculation of risk level for Major Adverse Cardiac Event (MACE) for 6 weeks, such as general mortality rate, MI, or coronary revascularization.

Aim of the study. To differentiate patients with chest pain that could be potentially infected with COVID19 and had low, intermediate, and high risk of Major Adverse Cardiac Event (MACE) during 6 weeks, such as general mortality rate, MI, need in coronary revascularization or coronary artery bypass surgery, and death.

Materials and methods. We differentiated 50 cases of admissions to the intensive care unit with the symptoms of expressed chest pain of unknown origin. Among patients, there were 5 potentially COVID-19 patients. 20-70-year-old males (average age was $49.02 \pm$ 1.73 years old) prevailed. All patients had been calculated points according to the HEART score (anamnesis, age, risk factors (smoking, obesity, family history, hypercholesterolemia, AH, DM, peripheral arterial disease), data of ECG, troponin I), as well as they were questioned if they had been suffering from a viral infection and about any possible contact with potential COVID-19 patients.

Results of the study. While calculating points according to the HEART score, we found $20 \%$ of people with low risk of MACE ( $2.4 \pm 0.12$ points), $44 \%$ with intermediate risk $(5.18 \pm 0.16$ points $)$, and $36 \%$ with high risk ( $7.83 \pm 0.26$ points).

Among 5 potential patients with COVID-19, who had complaints on chest pain and ST elevation on the ECG, got low troponin I levels after performed PCR and confirmed COVID-19 with further hospitalization to an infectious disease hospital.

The patients with low MACE risk did not need hospitalization and special examinations. Their chest pain was accompanied with physical and psychoemotional stress, musculoskeletal disorders and dysautonomia. 
Conclusions. Prediction of results for patients with chest pain or with acute myocardial infarction, who applied for emergency medical care, is performed with the help of the HEART score. A significant number of patients, who have an intermediate or high risk of MACE, have to be hospitalized immediately.

Keywords: HEART score, cardiovascular risk. 